\title{
FACTORS INFLUENCING THE PRODUCTIVITY OF COCONUT ESTATES
}

\author{
By \\ T.S.G. Peiris, M.T.N. Fernando and U.P. de S. Waidayanatha ${ }^{1}$
}

\begin{abstract}
The yield gap between the potential and actual productivity has been widening in coconut estates ( $>9$ ha) over the years. Among many reasons, the non-adoption and incorrect adoption of recommended agronomic and crop management practices on coconut cultivation have largely contributed to this yield gap. A survey carried out by the Coconut Research Institute (CRI) indicated that the lack of competent caretakers to correctly implement the crop management practices is a major reason to the yield gap and that there is an urgent demand for trained Farm Managers. Eight percent of the estates was identified as 'poor' with respect to the nut yield and the standard of the management practice adopted. Majority of both proprietors and caretakers $(75 \%)$ was not satisfied with the productivity of their estates. The performance of the estates was significantly associated with the land suitability class of coconut and the uses of recommend practices. About $75 \%$ of the caretakers had not received any training on coconut cultivation. According to the perception of the proprietors, males between 25-30 years of age are the best group to be trained as Farm Managers. The training course should include theory and practice on all aspects of coconut cultivation, intercropping, animal production, labour management, accounting procedures in estates, and the use of agricultural machinery.
\end{abstract}

\section{INTRODUCTION}

Coconut is important to Sri Lanka, both as a food crop and as industrial crop. The major part of the production (70\%) is used for local consumption and the balance is used for export as kernel products $(24 \%)$ and husked nuts $(1 \%)$. The percentage contribution of GDP by the coconut sector is 2.6 in 1998 (Central Bank, 1998). Annual coconut production during 1995-1999 has fluctuated between 2540 million nuts (in1999) with a mean of $2654( \pm 119)$ million nuts.

The annual coconut production is mainly influenced by the productivity of estate sector. The estates of more than 9 ha. represents $40 \%$ of the total bearing extent. The productivity of a coconut estate is determined by its land suitability classes for coconut, when other biotic factors are nonlimiting (Somasiri, et. al, 1994). An analysis of past data indicates that the gap between the potential and the actual coconut yield of the estate sector has been widening over the years in spite of the advances in agricultural technology and considerable efforts on subsidy programs of coconut (Peiris \& Samarajeewa, 1997).

Based on the population growth rate of $1 \%$ per year (Ministry of Health \& Women Affairs, 1994) and the annual consumption rate of 110 nuts per head (Sri Lanka Coconut Statistics, 1998), the requirement for domestic consumption in the year of 2005 would be 2185 million nuts. The rate of development of new coconut cultivation is fairly slow. Therefore, national production can be augmented essentially by increasing productivity of the exciting lands. Hence the importance of this for meeting the demand for both culinary and industrial purposes cannot be overlooked.

In view of this a survey was carried out to find the factors causing the yield gap and to identify necessary solution to increase the productivity of the coconut estates by minimizing yield gap.

${ }^{1}$ Coconut Research Institute ,Lunuwila 0024, Sri Lanka.. 


\section{DATA COLLECTION}

The field survey was conducted in the main coconut growing areas in Sri Lanka during the last quarter in 1998 to obtain the necessary information. Considering financial and time constraint and the ratio of the precision and the standard deviation, a sample of 100 estates was selected (Thattil, 1998). The sample design adopted was two-stage stratified random sampling (Cochran, 1962). Districts within the main coconut growing areas were the first stage of stratification and estates within each selected district was the second stage of stratification. The sample size for the three districts of Kurunegala, Gampaha and Puttalam and for the two groups of estates (9-23 ha \& $\geq 23$ ha) was determined by probability proportion to the number of estates within the respective groups (Sri Lanka Coconut Statistics, 1988). No prior stratification based on land suitability class for coconut is possible (Somasiri, et. al, 1994). Therefore, for land suitability class for coconut, post-stratification will be done.

The information on various aspects of the estates (general maintenance, recommended cultural practices, yield), details of the owners and caretakers, and desirable qualities of caretakers to be trained in future, etc. was obtained using a structured questionnaire. Both the caretaker (person who looks after the estate) and proprietor (owner of the estate) were interviewed separately. The caretakers were interviewed in the estate and the proprietors were interviewed at his /her residence (or working place) by an appointment. The overall response rate for the survey was $95 \%$.

\section{DATA ANALYSIS}

The data were analyzed using Statistical Analysis System (SAS 6.0, 1996). Various SAS procedures such as Proc GLM, CATMOD, SUMMARY, FREQ etc. were used.

\section{Status of the Estates, Caretakers and Proprietors}

\section{Status of the estates}

Of the estates, 51\% was mature plantations without under-plantation (MP), 30\% was from mature plantations with under-plantation (MPUP), and balance $19 \%$ was mixed plantations. About $80 \%$ of estates between 9-23 ha had sole ownership while $70 \%$ of estates above 23 ha had combined ownership. The majority of soil type of many estates was found to be sandy loam and clay loam. Most of the estates (75\%) had regular planting system, but the recommended density was found in only about $55 \%$ of estates. The detailed of type of plantation, recommended densities by the Coconut Research Institute is given by Mahindapala and Pinto (1992).

It was observed that the coconut palms were not numbered in about $70 \%$ of estates. Rainfall records were not kept by $97 \%$ and $65 \%$ of $9-23$ ha and $\geq 23$ ha respectively.

\section{Caretakers}

The estates are generally looked after by either by a supervisor or a watchman, but some estates had both. For purpose of this survey, the estates were grouped into two, namely: (a) the estates having a supervisor (or both supervisor and watchman), and (b) the estates having a watchman alone (Table 1).

The position of the person is significantly associated with the extent of the estate $(p=0.009)$. The percentage of supervisors is much higher in larger estates ( $\geq 23 \mathrm{ha}$ ) than that in medium size estates (9-23 ha). Nearly 20\% of the larger estates and 45\% medium estates are looked after by a watchman only. No female caretakers were found in the estates in this sample. 
The position of the caretaker was not significantly associated with the educational qualification and the majority of the caretakers had only a primary education. A low percentage (5\%) of young people ( $<30$ years) was engaged as caretakers in the estates. About $50 \%$ if supervisors and $30 \%$ of watchmen were over 50 years of age. The main source of income of about $90 \%$ of the caretakers is the salary drawn from the estates and other perks given by the proprietors.

Table 1. Status of the Caretakers.

\begin{tabular}{|c|c|c|c|}
\hline \multirow{2}{*}{ Extent of the estates (ha) } & \multicolumn{3}{|c|}{ Position } \\
\cline { 2 - 4 } & Supervisor & Watchman & Total \\
\hline $9-23$ & $19(54)$ & $16(46)$ & 35 \\
$\geq 23$ & $48(80)$ & $12(20)$ & 60 \\
Total & $67(70)$ & $28(30)$ & 95 \\
\hline
\end{tabular}

(Values in parenthesis are row percentages, $\chi_{(1)}^{2}=7.03, \mathrm{p}=0.009$ )

Table 2 indicates that $66 \%$ of the supervisors and $96 \%$ of the watchmen have not followed any training conducted by the Coconut Research Institute (CRI) or Coconut Cultivation Board (CCB).

Table 2. Participation in training in coconut cultivation by the caretakers

\begin{tabular}{|c|c|c|c|}
\hline \multirow{2}{*}{$\begin{array}{c}\text { Position of the } \\
\text { caretaker }\end{array}$} & Yes & Participation & \multirow{2}{*}{ Total } \\
\cline { 2 - 3 } & $23(34)$ & $44(66)$ & 67 \\
\hline supervisor & $1(4)$ & $27(96)$ & 28 \\
watchman & $24(25)$ & $71(75)$ & 95 \\
Total & &
\end{tabular}

(Values in parenthesis are row percentages, $\chi_{(1)}^{2}=9.89, \mathrm{p}=0.002$ )

\section{Status of the proprietors}

The main occupation of the proprietors varied from planters to highly qualified professions. The majority of the coconut estates are owned by businessmen followed by professionals and hence the time devoted to their coconut estates in restricted by the nature of their profession. Irrespective of the size of the estates about $80 \%$ of the proprietors are absentee landowners. The percentage of proprietors who had participated in a training program on coconut cultivation varied from $12 \%$ of businessman to $25 \%$ of the planters.

\section{Knowledge on technologies related to coconut cultivation}

The awareness of the correct methodology of various aspects on coconut cultivation recommended by the CRI was assessed separately from the proprietors and the caretakers (Table 3 ).

Results indicate that the level of knowledge of both caretakers and the proprietors on the important aspects of technology relevant to coconut production is not satisfactory except the caretakers' knowledge on correct identification of seedling and the beneficial effects of NETs. Thus it indicates the serious dearth of competent caretakers to look after coconut estates. 
Table 3. Knowledge of caretakers and proprietors about correct technologies of coconut production ( in \%)

\begin{tabular}{|l|c|c|}
\hline \multicolumn{1}{|c|}{ Type of technology recommended by the CRI } & Proprietors & Caretakers \\
\hline Method of seed nut selection & $27 \%$ & $34 \%$ \\
Identification of good seeding & $35 \%$ & $52 \%$ \\
Use of correct fertilizer & $35 \%$ & $46 \%$ \\
Identification of deficiency symptoms of K & $22 \%$ & $32 \%$ \\
Diagnosis of dolomite deficiency & $28 \%$ & $45 \%$ \\
Beneficial effects of nitrogen fixing trees (NFTs) & $38 \%$ & $56 \%$ \\
\hline
\end{tabular}

\section{Performance of Estates}

\section{Assessment of cultural practices in coconut}

Important and economically viable cultural practices on coconut cultivation recommended by the CRI (Mahindapala and Pinto, 1992) include application of correct amount and method of fertilizer (CORFER), establishment of mulch (MULCH), husk-pits (HUSKPTS), cover crops (COVERC), and contour drains (CONTDR). If the correct amount and method of application is done as recommended by the CRI, it was classified as 'correct', otherwise as 'not correct' by the survey team. Similarly each of other cultural practice (MULCH, HUSKPTS, COVERC and CONTDR) was classified as 'satisfactory' and 'not satisfactory' based on adaptation according to CRI recommendation.

The percentage of estates where each practice was not satisfactory is close to $75 \%$ irrespective of land size, the type of the caretaker or land suitability class for coconut. This could be due to lack of knowledge on correct implementation of cultural practices. This situation directly affects the level of production of the estate.

\section{Association of performance of estates with each factor}

The general performance of the estate was grouped into two states namely 'good' and 'poor' based on visual observation of the palms, as it is the good indicator for the expected nut production. Of course this can be done accurately by the members of the survey team. It was found that $84 \%$ of estates in the sample was in poor state. Also the majority of the proprietors and the caretakers expressed that they were not satisfied with the production because they have not achieved the potential output from their lands. The associations of the performance of estates with various factors were tested using 2-way contingency tables (Tables 4 to 8).

Table 4. Association between the land suitability classes for coconut and performance of estates.

\begin{tabular}{|c|c|c|c|}
\hline \multirow{2}{*}{$\begin{array}{c}\text { Land suitability class for coconut } \\
\text { (LANDSSC) }\end{array}$} & \multicolumn{2}{|c|}{ Performance of the estate } & \multirow{2}{*}{ Total } \\
\hline & Good & Poor & \\
\hline Class $1 \& 2\left(S_{1}\right.$ and $\left.S_{2}\right)$ & $9(27)$ & $24(73)$ & 33 \\
\hline Class $3 \& 4\left(S_{3}\right.$ and $\left.S_{4}\right)$ & $2(3)$ & $60(97)$ & 62 \\
\hline Total & 11 & 84 & 95 \\
\hline
\end{tabular}

(Values in parenthesis are row percentages, $\chi_{(1)}^{2}=12.16, p=0.001$ ) 
Of the four land suitability classes for coconut $-\mathrm{S}_{1}, \mathrm{~S}_{2}, \mathrm{~S}_{3}$ and $\mathrm{S}_{4}$ (Somasiri, et. al, 1994) the data on $S_{1} \& S_{2}$ and $S_{3} \& S_{4}$ were pooled together by consulting the soil scientist for this analysis. The level of performance of estates was significantly associated with the land suitability classes for coconut $(\mathrm{P}=0.001)$. The proportion of good performance estates in $\mathrm{S}_{1} \& \mathrm{~S}_{2}(27 \%)$ was much higher than that in $\mathrm{S}_{3} \& \mathrm{~S}_{4}(3 \%)$. The proportion of poor performance estates in $\mathrm{S}_{3} \& \mathrm{~S}_{4}$ was $97 \%$ as against the corresponding proportion of $73 \%$ in $S_{1} \& S_{2}$. The level of performance was not significantly associated with the extent of the estate.

Table 5. Associations between correct application of fertilizer (amount \& method) for adult palms and performance of the estate

\begin{tabular}{|c|c|c|c|}
\hline \multirow{2}{*}{$\begin{array}{c}\text { Method and amount of fertilizer } \\
\text { (CORFER) }\end{array}$} & \multicolumn{2}{|c|}{$\begin{array}{c}\text { Level of performance of the } \\
\text { estate }\end{array}$} \\
\cline { 2 - 3 } & Good & Poor & \\
\hline Correct & $8(19)$ & $33(81)$ & 41 \\
Not correct & $3(5)$ & $51(95)$ & 54 \\
Total & 11 & 84 & 95 \\
\hline
\end{tabular}

(Values in parenthesis are row percentages, $\chi_{(1)}^{2}=4.34, \mathrm{p}=0.035$ )

The level of performance of the estates was significantly associated $(\mathrm{P}=0.035)$ with the use of correct method and amount of fertilizer for adult palms. Estates that adopted both method and amount of fertilizer correctly had the highest percentage of good performing estates (19\%) as against the estates where both amount and method of fertilizer is incorrectly applied.

Table 6. Association between status of mulch and performance of the estate

\begin{tabular}{|c|c|c|c|}
\hline \multirow{2}{*}{$\begin{array}{c}\text { Status of mulch } \\
\text { (MULCH) }\end{array}$} & \multicolumn{2}{|c|}{ Level of performance of the estate } & \multirow{2}{*}{ Total } \\
\cline { 2 - 3 } & Good & Poor & 25 \\
\hline Satisfactory & $7(28)$ & $18(72)$ & 70 \\
Not satisfactory & $4(6)$ & $66(94)$ & 95 \\
Total & 11 & 84 & \\
\hline
\end{tabular}

(Values in parenthesis are row percentages, $\chi_{(1)}^{2}=8.94, p=0.003$ )

The status of mulching in the estates was significantly associated with level of performance of the estates $(\mathrm{P}=0.003)$. Percentage of good performing estates was higher when mulch was established satisfactorily than that when mulch was established satisfactorily. Nearly $95 \%$ estates were classified as poor among the estates established mulch unsatisfactorily.

Table 7. Association between status of husk pits and performance of the estate

\begin{tabular}{|c|c|c|c|}
\hline \multirow{2}{*}{$\begin{array}{c}\text { Status of husk pits } \\
\text { (HUSKPTS) }\end{array}$} & \multicolumn{2}{|c|}{ Level of performance of the estate } & \multirow{2}{*}{ Total } \\
\cline { 2 - 3 } & Good & Poor & \\
\hline Satisfactory & $7(26)$ & $20(74)$ & 27 \\
Not satisfactory & $4(6)$ & $64(94)$ & 68 \\
Total & 11 & 84 & 95 \\
\hline
\end{tabular}

(Values in parenthesis are row percentages, $\chi_{(1)}^{2}=7.58, \mathrm{p}=0.006$ ) 
The status of husk pits in the estates was significantly associated with level of performing estates $(\mathrm{P}=0.006)$. Of the estates adopted husk pits satisfactory, $26 \%$ was classified as good estates. The percentage of good perform estates of which husk pits were not at satisfactory level was $6 \%$.

It was found that the status of cover crops (COVERC) was not significantly associated with the performance of estates.

Table 8. Association between status of contour drains and performance of the estate

\begin{tabular}{|c|c|c|c|}
\hline \multirow{2}{*}{$\begin{array}{c}\text { Status of contour drains } \\
\text { (CONTDR) }\end{array}$} & \multicolumn{2}{|c|}{ Level performance of the estate } & \multirow{2}{*}{ Total } \\
\cline { 2 - 3 } & Good & Poor & 29 \\
\hline Satisfactory & $8(28)$ & $21(72)$ & 66 \\
Not satisfactory & $3(4)$ & $63(96)$ & 95 \\
Total & 11 & 84 & \\
\hline
\end{tabular}

(Values in parenthesis are row percentages, $\chi_{(1)}^{2}=10.45, \mathrm{p}=0.001$ )

The status of the contour drains was also significantly associated with the level of performance of the estates $(\mathrm{P}=0.001)$. Estates that adopted contour drains satisfactorily had the highest percentage of good performing estates (28\%) as against the estates that adopted contour drains unsatisfactorily (4\%).

The status of the residence on the estate by the proprietors or their training on coconut cultivation was not significantly associated with the performance of the estates. Also no significant association was found between the performance of the estates and the status of training received by the caretakers, the percentage of good estates was higher where trained caretakers maintain estates.

\section{Interaction between factors on the performance of estates}

The limitation with the above 2-way separate analysis is that the effect of each factor is not adjusted for the effect of other factors (Krzanowski, 1990). In order to study each of the independent effects simultaneously, linear logistic model was fitted. The reason to fit a linear logistic model is that the response variable (performance of estates) is a binary variable (recorded as either good or bad) and the analysis of binary data is done by fitting a linear logistic model (Krzanowski, 1990). Only the two land suitability groups and five cultural practices were considered for the model. The linear logistic model was fitted using Catmod Procedure in SAS. The analysis of variance is shown in Table 9.

Table 9. Results of maximum-likelihood analysis of variance.

\begin{tabular}{|l|c|c|c|}
\hline \multicolumn{1}{|c|}{ Source } & DF & Chi -square value & Probability level \\
\hline Intercept & 1 & 8.68 & 0.0032 \\
LANDSSC & 1 & 8.06 & 0.0045 \\
CORFER & 1 & 4.29 & 0.0383 \\
MULCH & 1 & 2.28 & 0.1314 \\
HUSKPT & 1 & 0.74 & 0.3908 \\
CONTDR & 1 & 0.07 & 0.7897 \\
COVERC & 1 & 1.05 & 0.3056 \\
Likelihood ratio (LR) & 31 & 35.97 & 0.2471 \\
\hline
\end{tabular}


The non-significance of the likelihood ratio in Table 9 indicates the adequacy of the model. It indicates that there is no interaction between factors with respect to performance. Results (Table 9) indicate that the land suitability class for coconut (LANDSSC) and the correct amount and method of fertilizer application (CORFER) were significant when all factors were considered together. Therefore LANDSSC and CORFER are the most important factors that govern the performance of coconut estates. Results also showed that coefficients for all the five cultural practices are positive, indicating that the estates of which the above cultural practices are correctly practiced are more likely to have more productive palms than the estates of which cultural practices are incorrectly adopted.

\section{Yield gap}

When the above five cultural practices are correctly adapted, the potential yield per palm per year in soil suitability classes $S_{1} S_{2}, S_{3}$ and $S_{4}$ are 93, 78, 68 and 47 respectively (Somasiri, et. al, 1994). The yield gap was thus defined the difference between the potential yield per palm per year and observed mean yield based on 1996 and 1997 acquired from the survey data by excluding estates where data was not available. A general linear model was fitted using SAS to find the factors influencing on yield gap (Table 10).

Table 10. Results of the Anova for the Dependant variable 'yield gap'

\begin{tabular}{lccc}
\hline \multicolumn{1}{c}{ Factor } & DF & sum of squares & probe $>$ F \\
\hline LANDSSC & 1 & 4,410 & 0.0001 \\
CORFER & 1 & 950 & 0.0100 \\
MULCH & 1 & 363 & 0.1037 \\
HUSKPT & 1 & 61 & 0.5004 \\
CONTDR & 1 & 658 & 0.0030 \\
COVERC & 1 & 36 & 0.6000 \\
Error & 47 & 6,092 & \\
\hline
\end{tabular}

(Model R-square $=0.54 ; \mathrm{p}=0.0001$ )

Two factor and higher order interactions were not significant. Results indicate that yield gap is significantly different between land suitability classes for coconut, the status of application of fertilizer (correct amount and method) and the status of contour drains. In fact, the CONDR was not come out as a significant factor for the performance of estates.

\section{Farm Managers to be Trained}

\section{Demand for farm managers}

The demand for Farm Managers was significantly associated with the extent of estate $(\mathrm{P}=$ 0.044). The percentage of proprietors who directly mentioned that they urgently need a person trained by the Coconut Research Institute (CRI) was 22\% and 33\% from over 23 ha and 9-23 ha estates respectively. The percentage of proprietors, who expressed that they would consider taking such a farm manager, once a vacancy arises, was $71 \%$ and $48 \%$ in the two groups respectively. The rest of the proprietors expressed that they would not need such farm managers.

\section{Competence of farm managers to be trained}

According to the response of proprietors, the competence required quality of Farm Managers were not associated on the extent of estate. All the proprietors preferred males to be trained. The majority of the proprietors preferred 25-30 years of males having three passes in G.C.E. (A. L.) bioscience or agriculture to recruit as Farm Managers. 
About 50\% expressed that the training should be given to fresh persons while other $50 \%$ liked if the persons having some experience in coconut cultivation are trained. Further, most of the proprietors felt that the knowledge in biology, enthusiasm for agriculture, good family background, energetic and ability to take decision are additional factors to be considered in selecting their farm managers.

\section{Areas to be included in the training course}

All the proprietors felt that the trainees should undergo a complete practical training on all aspects of coconut cultivation for a minimum of three month. Further they suggested that they expect good knowledge of intercropping and animal husbandry, maintenance of accounts on estate activities, labour handling and the use of machines for various cultural practices from the Farm Managers.

\section{DISCUSSION}

More than $80 \%$ of the coconut estates ( $\geq 23$ ha) is with absentee landlords and about $60 \%$ is owned by large-scale businessmen and professionals in various disciplines. Irrespective of the states of the proprietors, the productivity of almost all the coconut estates was below the potential. Majority of estates was looked after by untrained and incompetent persons and there was no correct implementation of CRI recommendations. Almost all the proprietors had realized that in addition to uncontrollable factors, the lack of competent caretakers was a major factor for poor status and low productivity. The correct amount and method of application of fertilizer, and contour drains had significantly influenced keeping the yield gap low.

There is a good demand for Farm Managers trained by the CRI. The demand for Farm Managers was significantly associated with the extent of estate. According to the preference of the proprietors, males between 25-30 years of age having at least thr5ee passes of G. C. E. (A.L.) with bioscience and /or agriculture and with or without experience in coconut cultivation is the best group to be selected for the training. Further most of the proprietor's felt that the enthusiasm for agriculture, and personality are additional factors to be considered in selecting Farm Managers. In addition to training on all the aspects of coconut cultivation, intercropping and animal production, the course should also aim to give good training on other estate activities such as maintenance of accounts and check role, labour management and the use of machinery for various operations on coconut estates.

\section{CONCLUSION}

The productivity of the coconut estates can be improved through the use of trained farm mangers. However, there is dearth of trained farm mangers. Thus, it is necessary to implement a three months training program on all aspects of coconut cultivation.

Acknowledgement: The authors are grateful to Mr. D T Mathes, Dr. H.A.J. Gunathilake and Dr. L L W Somasiri (CRI) for their assistance, and Mrs. S. Samarajeewa, Messers. S. Senarathne, S. Rajapakse, S.D.J.N. Subasinghe, Bandula Perera, I Ubayarathne, E.M. Gunarathne Banda and P.B.A. Caldera (CRI) for their efficient support to conduct the survey and Dr. S. Samita from the university of Peradeniya for his valuable comments on this paper. The study was funded by the coconut CESS Committee. 


\section{REFERENCES}

Central Bank of Ceylon (1998). Annual Report of the Central Bank of Ceylon, Colombo. 39 p.

Cochran, W. G. (1962). Sampling Techniques, Second Edition, John Wiley \& Sons, Inc, New York $76 \mathrm{p}$

Krzanowski, W. J. (1990). Principals of Multivariate Analysis: A Users's Perspective. Oxfarod University Press, UK

Mahindapa, R. and Pinto, J. L. J. J. (1992). Coconut Cultivation. Publication of Coconut Research Institute, Lunuwila, Sri Lanka.

Ministry of Health and Women's Affairs (1994). Population impacts on development.

Peiris, T S G and Samarajeewa, S.(1997). Evaluation of coconut subsidy on coconut subsidy programs. 1-128pp. (Publication of CRI, Lunuwila, Sri Lanka).

SAS (1996). SAS/STAT User's guide for personnel computers, Version $6,4^{\text {th }}$ Edition, Cary, NC, USA, SAS Institute Inc.

Somasiri, L.L. W., Nadarajah, N., Amarasinghe. L. and Gunathilake, H.A.J.(1994). Land suitability assessment of coconut growing area in the coconut triangle. Occasional Publication Series, Coconut Research Institute, Sri Lanka.

Sri Lanka Coconut Statistics (1988). Annual publication of the Coconut Development Authority, Colombo, Sri Lanka.

Thattil, R. O. (1998). Handbook on Survey Design and Analysis. Publication of Postgarduate Institute of Agriculture, University of Peradeniya. 